\title{
Food sharing in albino rat pups: Does familiarity breed contempt?
}

\author{
GEORGIA D. WILLS, FRANK R. MOORE, ANDREA L. WESLEY, \\ and BARRY FRIEDMAN \\ University of Southern Mississippi, Hattiesburg, Mississippi
}

\begin{abstract}
The present experiment investigated the effects of kinship and familiarity upon food sharing in pairs of albino rat pups. Five pairs of rats from each of the following groups were tested: (1) familiar siblings, (2) nonfamiliar siblings, (3) familiar nonsiblings, and (4) nonfamiliar nonsiblings. A small food portion was used, necessitating not only close physical contact, but also cooperation in the sense that both pups were required to remain relatively immobile in order for both to feed simultaneously. Results indicated more frequent sharing among unfamiliar pups, whether related or not. Results also indicated that food sharing increased in frequency among all four groups over the 5-day testing period, suggesting that cooperation in the form of food sharing can develop, or increase in frequency, over time in albino rat pups.
\end{abstract}

The study of interactions among siblings has become a topic of interest in the last few years, and most researchers using rodents as subjects have examined affiliative preferences among siblings and nonsiblings, as well as the underlying mechanisms mediating sibling recognition. Porter, Tepper, and White (1981), Porter and Wyrick (1979), and Porter, Wyrick, and Pankey (1978) examined affiliative preferences among spiny mice (Acomys cahirinus), including huddling preferences, and reported affiliative preferences among familiar agemates, whether related or not. On the other hand, Kareem and Barnard (1982) reported that, in mice, subjects demonstrated the ability to discriminate between unfamiliar paternal half-siblings and unfamiliar, unrelated conspecifics. Similarly, Grau (1982) reported that whitefooted deermice reared in the lab can distinguish between siblings and nonsiblings without prior exposure.

Studies of social preferences among albino rat subjects are relatively scarce. Tolman (1961) examined affiliative preferences among 21-day-old littermates and unfamiliar agemates, and reported social preferences for unfamiliar agemates over littermates. Additionally, Stevens (1981) found preferences for unfamiliar agemates over sibling rat pups in an investigation of play behavior. Aside from these studies, there is little information on how kinship might affect social interactions in Rattus norvegicus.

In the present investigation, we wanted to evaluate the effects of kinship and familiarity upon cooperative food sharing. Daniel (1942) demonstrated food sharing among albino rat subjects using an operant conditioning paradigm. More recently, Porter, Moore,

The authors' mailing address is: Department of Psychology, University of Southern Mississippi, Box 5025 Southern Station, Hattiesburg, MS 39406. and White (1980) demonstrated food sharing in spiny mice. A stationary food cup was used, which had a single opening large enough for two rats to feed simultaneously, but which necessitated close physical contact. The authors reported more frequent food sharing among familiar siblings than among unfamiliar nonsiblings.

Investigations in this laboratory have shown that when given a standard-size food pellet of the kind typically used in laboratories maintaining rats (Purina Laboratory Chow), two hungry rats are not likely to feed on the pellet at the same time. Instead, competition is observed in the form of one rat taking, or attempting to take, the pellet from the other. However, it has been observed that, if given a slightly larger portion of food (Milk Bone Dog Biscuits, small; $4.5 \times 2 \mathrm{~cm}$ ), pairs of rat pups sometimes feed on the biscuit simultaneously. For this reason, the small biscuit was selected to be used in this experiment. Simultaneous feeding on the biscuit necessitated not only close physical proximity, but cooperation in the sense that the two pups would have to remain in a relatively fixed, or immobile, position. Food sharing was operationally defined as simultaneous feeding by both rats. Thus, the purpose of the present investigation was to determine the effects of kinship and familiarity upon simultaneous feeding, or food sharing.

\section{METHOD}

\footnotetext{
Subjects

Twenty pairs of rat pups were drawn from 10 litters of SpragueDawley rat pups which were bred and born in the Psychology Department breeding colony. Within $24 \mathrm{~h}$ after birth, four pups from each of two litters were removed from their home cages and placed into a cage containing an unfamiliar foster mother and foster siblings. That is, pups of the same age were exchanged between two litters, with the family units in each home cage remaining other-
} 
wise intact. Foster pups remained with their foster families until testing was completed.

The subjects were weaned at 21 days of age, and then the litters were subdivided by sex. The animal laboratory was maintained on a 14:10 light-dark cycle. Food and water were available ad lib until testing began, at which time the subjects were placed on a 22-h food-deprivation schedule for the duration of the 5-day testing period. The litters were housed in stainless steel cages, $60 \times$ $44 \times 35 \mathrm{~cm}$. The 20 pairs of subjects were matched for sex, and all were between 25 to 35 days of age at the time testing began.

\section{Apparatus}

The observation cage was stainless steel and measured $60 \times$ $44 \times 35 \mathrm{~cm}$.

\section{Procedure}

Two food-deprived rats were placed in the observation cage with a single portion of food (Milk Bone Dog Biscuits, $4.5 \times 2 \mathrm{~cm}$ ). The experimenter recorded the length of time (in seconds) each rat spent feeding alone and the length of time (in seconds) the pups fed simultaneously.

Five pairs of each of the following combinations were tested: (1) two familiar siblings, or siblings reared together, (2) two nonfamiliar siblings, or siblings reared apart, (3) familiar nonsiblings, or foster littermates, and (4) two unfamiliar, unrelated agemates. Each pair was tested daily for 5 consecutive days. Sessions were 10 min in length.

\section{RESULTS}

The independent variables were biological relatedness vs. nonrelatedness and familiarity vs. nonfamiliarity among the subjects, and trials (5). The dependent measures were the length of time each animal spent feeding along on the biscuit, and the length of time both animals fed on the biscuit simultaneously. A $2 \times 2 \times 5$ ANOVA, repeated measures, was used, with the .05 level chosen to evaluate the significance of the differences among the groups.
The amounts of time the more active animals of the pairs spent feeding alone were compared among the four groups (see Table 1). Statistical analysis indicated that the time spent feeding alone by the more active members of the pairs was appreciably longer in the familiar groups than in the nonfamiliar groups $[F(1,16)=9.35, p=.008]$. These patterns did not change over the 5 -day testing period.

The second dependent measure was the amount of time both pups of a pair fed on the biscuit simultaneously (see Table 2). Statistical analysis indicated that pairs from the nonfamiliar groups, both related and nonrelated, spent more time feeding from the food biscuit simultaneously than the familiar pairs, both related and nonrelated $[F(1,16)=9.92, p=.006]$. An important finding was that foodsharing increased significantly for all groups over the 5-day testing period $[F(4,64)=12.56$, $p<.001]$.

\section{DISCUSSION}

Food sharing is a complex social interaction that has been demonstrated among rodent conspecifics on very few occasions (Daniel, 1942; Porter, Moore, \& White, 1980). It is, therefore, significant that the present experiment demonstrated food-sharing behavior among rodent conspecifics. It is also of interest that we demonstrated increases in the frequency of food sharing over time.

Probably the most interesting and counterintuitive finding was that the unfamiliar pairs of pups fed together more frequently than the familiar pairs. These results are opposite to previous findings (Porter et al., 1980) that spiny mice siblings fed together longer

Table 1

Time (in Seconds) the More Active Member of Each Pair Fed Alone

\begin{tabular}{|c|c|c|c|c|c|c|c|c|}
\hline & \multicolumn{2}{|c|}{ Familiar Siblings } & \multicolumn{2}{|c|}{ Nonfamiliar Siblings } & \multicolumn{2}{|c|}{ Familiar Nonsiblings } & \multicolumn{2}{|c|}{ Nonfamiliar Agemates } \\
\hline $\begin{array}{l}\text { Day } 1 \\
\text { Day } 2 \\
\text { Day } 3 \\
\text { Day } 4 \\
\text { Day } 5\end{array}$ & $\begin{array}{l}298.00 \\
270.70 \\
129.79 \\
278.59 \\
212.00 \\
\end{array}$ & $\begin{array}{l}131.98 \\
119.17 \\
134.96 \\
232.93 \\
211.22\end{array}$ & $\begin{array}{r}97.79 \\
144.79 \\
81.59 \\
76.00 \\
59.59 \\
\end{array}$ & $\begin{array}{r}114.44 \\
114.44 \\
54.50 \\
60.56 \\
89.18\end{array}$ & $\begin{array}{r}129.00 \\
149.39 \\
30.79 \\
149.20 \\
140.79\end{array}$ & $\begin{array}{r}147.07 \\
91.01 \\
33.11 \\
106.54 \\
121.20\end{array}$ & $\begin{array}{r}118.00 \\
126.59 \\
101.79 \\
81.59 \\
24.39\end{array}$ & $\begin{array}{r}106.21 \\
45.50 \\
124.24 \\
134.33 \\
14.27\end{array}$ \\
\hline
\end{tabular}

Note $-n=5$ pairs.

Table 2

Time (in Seconds) Pairs Spent Sharing Food

\begin{tabular}{|c|c|c|c|c|c|c|c|c|}
\hline & \multicolumn{2}{|c|}{ Familiar Siblings } & \multicolumn{2}{|c|}{ Nonfamiliar Siblings } & \multicolumn{2}{|c|}{ Familiar Nonsiblings } & \multicolumn{2}{|c|}{ Nonfamiliar Agemate } \\
\hline & Mean & SD & Mean & SD & Mean & SD & Mean & SD \\
\hline Day 1 & 25.59 & 57.24 & 119.20 & 136.19 & 26.20 & 58.58 & 36.20 & 56.25 \\
\hline Day 3 & 2.00 & 4.47 & 173.59 & 169.44 & 139.47 & 139.47 & 170.60 & 170.60 \\
\hline Day 4 & 50.79 & 113.59 & 277.00 & 144.28 & 97.59 & 124.85 & 276.79 & 136.05 \\
\hline Day 5 & 46.59 & 69.65 & 324.79 & 161.90 & 197.59 & 210.77 & 326.19 & 143.11 \\
\hline
\end{tabular}

Note $-n=5$ pairs. 
than unrelated agemates. Findings from the Porter et al. study have been interpreted as support for kin selection theory (Hamilton, 1963, 1964). Food sharing was regarded as a form of altruism and was expected to occur more frequently among related individuals than among nonrelated individuals. Results from the present investigation, however, do not warrant a similar interpretation and suggest that not all instances of apparent altruism can be viewed in the light of kin selection theory. Natural selection need not favor food sharing among relatives under all environmental conditions. In albino rats, other patterns of sibling interactions may take precedence over food sharing.

One possibility may be that competition during the first few days and weeks of life (the nursing period) requires the development of dominance/submission patterns of sufficient strength that preclude the possibility of sibling food sharing. It is well established that competition among albino rat pups begins during the nursing period (Bolles \& Woods, 1964), and that dominance/submission patterns develop when rats are housed together for any length of time (Barnett, 1963; Mowrer, 1960). The finding that the more active members of pairs from the familiar groups fed alone longer than the nonfamiliar, active members may lend support for this possibility. A possible area for further inquiry may be to examine dominance/ submission patterns during nursing, and perhaps to compare the effects of differential litter sizes on later food sharing by comparing relatively small litters with larger litters.

\section{REFERENCES}

Bannett, S. (1963). The rat. Chicago: Aldine.

Bolles, R., \& Woods, P. (1964). The ontogeny of behavior in the albino rat. Animal Behaviour, 12, 427-441.

DANIEL, W. (1942). Comparative problem solving in rats. Journal of Comparative Psychology, 34, 361-368.

GraU, H. (1982). Kin recognition in white-footed deermice (Peromyscus leucopus). Animal Behaviour, 30, 497-505.

Hamilton, W. (1963). The evolution of altruistic behavior. American Naturalist, 97, 354-356.

Hamilton, W. (1964). The genetical evolution of social behavior. Journal of Theoretical Biology, 7, 1-52.

KAREEM, A., \& BARNARD, C. (1982). The importance of kinship and familiarity in social interactions between mice. Animal Behaviour, 30, 584-601.

Mowrer, O. (1960). Learning theory and the symbolic process. New York: Wiley.

Porter, R., Moone, J., \& White D. (1980). Food sharing by sibling versus nonsibling spiny mice. Behavior Ecology and Sociobiology, 8, 207-212.

Ponter, R., Tepper, V., \& White, D. (1981). Experiential influences on the development of huddling preferences and "sibling" recognition in spiny mice. Developmental Psychobiology, 14, 375-382.

Porter, R., \& Wyrick, M. (1979). Sibling recognition in spiny mice: Influence of age and isolation. Animal Behaviour, 27, 761-766.

Porter, R., Wyrick, M., \& PAnKey, J. (1978). Sibling recognition in spiny mice. Behavior Ecology and Sociobiology, 3, 61-68.

Stevens, S. (1981). Play behavior in Rattus norvegicus: Development of research method and analysis of play deprivation. Unpublished doctoral dissertation, Indiana University.

Tolman, C. (1961). Social preference in the albino rat pup. Psychological Reports, 8, 522.

(Manuscript received February 15, 1983; revision accepted for publication October 21, 1983.) 